\section{M’Naghten Rule}

Nathalie DeFabrique

Cook County Department of Corrections,

Chicago, IL, USA

\section{Synonyms}

M'Naghten test

\section{Definition}

Historically, insanity was not considered a defense, but was a way to be acquitted from a crime as a result of a mental illness. The test was named after Daniel M'Naghten, a British man who was a defendant in a murder case in 1843 . He was acquitted due to being found insane. The M'Naghten test or M'Naghten rule states that a person may be insane if at the time of committing the crime, the accused person was under the effect of mental illness and did not know the nature or quality of the act he was doing. If the person accused did know what he was doing, the M'Naghten test assesses whether the person knows what he did was wrong.

\section{Cross-References}

- Actus Reus

- Insanity

- Insanity Defense

- Mens Rea

\section{References and Readings}

American Law Institute. (1955). Model penal code. Philadelphia: American Law Institute.

Dalby, J. T. (2006). The case of Daniel McNaughton: Let's get the story straight. American Journal of Forensic Psychiatry, 27, 17-32.

Denney, R. L. (2005). Criminal responsibility and other criminal forensic issues. In G. Larrabee (Ed.), Forensic neuropsychology: A scientific approach. New York: Oxford University Press.

M'Naughten's Case, 10 Clark \& Finnelly 200 (1843).

Melton, G. B., Petrila, J., Poythress, N. G., \& Slobogin, C. (2007). Psychological evaluations for the courts (3rd ed.). New York: Guilford.

Rogers, R., \& Shuman, D. (2000). Conducting insanity evaluations (2nd ed.). New York: Guilford.

Shapiro, D. L. (1999). Criminal responsibility evaluations: A manual for practice. Sarasota: Professional Resource Press.

Yates, K. F., \& Denney, R. L. (2008). Neuropsychology in the assessment of mental state at the time of the offense. In R. Denney \& J. Sullivan (Eds.), Clinical neuropsychology in the criminal forensic setting. New York: Guilford. 